\title{
Study on Properties of Concrete with Iron Ore Tailing and Glass Waste
}

\author{
Sushmitha $\mathrm{KS}^{1}$, Dhanabal $\mathrm{P}^{2 *}$ \\ ${ }^{1}$ Department of Transportation Engineering \& Management, Reva University, Bangalore, Karnataka, India \\ ${ }^{2}$ Department of Structural Engineering, Government College of Engineering, Salem, Tamil Nadu, India \\ * Corresponding author email: dhanabalgce@gmail.com
}

Received: 01 May 2021 / Revised: 07 September 2021 / Accepted: 07 November 2021 / Published: 04 December 2021

\begin{abstract}
The aim of this research is to test the characteristics of concrete by substitute fine aggregate with iron ore tailings and partial glass powder as in the place of cement. Concrete with waste products such as glass powder and iron ore tailings offer technical, economic and environmental advantages. In this experimental investigation, glass powder is replaced with cement by $10 \%, 20 \%$ and $30 \%$ and iron ore tailings with fine aggregates by $30 \%$ which is the optimum percentage. To study the role of glass powder and iron ore tailings combination in concrete. The properties such compressive strength, flexural strength, tensile strength and also durability parameters likely water absorption investigation for M40 concrete is carried out with different percentages of glass powder by keeping the iron ore tailings percentage constant. At $30 \%$ glass powder substitution as cement and sand with IOT increases concrete effectiveness. The concrete with $10 \%$ glass powder \& $30 \%$ iron ore tailings showed a higher strength compared to the conventional mix for 28 days. Concrete mix containing $10 \%$ GP and 30\% IOT showed higher flexural strength of $5.05 \mathrm{MPa}$ for 28 days. Splitting tensile strength value is also increasing i.e., for $10 \%$ glass powder and $30 \%$ IOT, obtained splitting tensile strength was $4.48 \mathrm{MPa}$ and modulus of elasticity value was has also increased. Water absorption experiment consequences results that water absorption decreases with an increase in GP percentage. The concrete workability tends to decrease when with glass powder content increase. Concrete containing $10 \%$ glass powder and $30 \%$ IOT showed maximum strength and it is considered as the optimum dosage.
\end{abstract}

Keywords: Glass powder, Iron ore tailing, Concrete properties.

\section{Introduction}

Concrete is one of the most unique construction materials. It is also used in rigid pavement in roadways. The scarcity of ingredients (cement and fine aggregate) in concrete is a major issue nowadays. We are in need to found alternate materials in construction. So, in this work we made an attempt of utilising combined of Iron ore tailing as a replacement material for cement and glass waste as a replacement material for cement. Iron ore tailings is one of the mine wastes which is available in India. To minimize the negative impact of IOT on environment and low-cost construction, this can be utilized in concrete production as substitute of fine aggregate [1-5]. The viability of the tailings of iron ore as a substitute material on behalf of FA in the concrete for construction of concrete pavements. The transformation of fly ash and IOT into foaming geopolymer leads to the formation of porous structure encouraging $\mathrm{Cu} 2+$ sorption [6-9]. The Size distribution curve of composite binder containing IOT was very close optimization curve. So, By Adding the IOT Packing density increased [10-14]. Water to binder ratio reduced means, it will give maximum strength. Also, IOT Substitution in with nominal percentage increases the compressive strength of concrete [15-18]. Glass powder is a kind of pozzolanic material because it has that nature and characteristics. Use of glass powder has much influence in setting time and cement expansion [19-22]. Concrete with cement replaced by $15 \%$ and $30 \%$ glass powder gives more strength as well as lowest porosity [23,24]. The maximum compressive strength (136 MPa) was arrived when $20 \%$ glass waste added in RPC-Reactive 
Study on Properties of Concrete with Iron Ore Tailing and Glass Waste

powder concrete [25]. Concrete with Fly ash and glass waste gives improvement in durability characteristics. Concrete with 20 percentages gives the nominal strength as compared to conventional concrete [26-28]. So, from the literature review it's known that iron ore tailing and glass waste can be used as a replacement material for fine aggregate and cement respectively in concrete. Our Aim and Objective of this study is to combine iron ore tailing and glass waste as a replacement material for sand and cement respectively, then evaluate fresh, hardened and water absorption properties of concrete with and without IOT and glass waste replacement.

\section{Materials and Methods}

The current study started with literature review. Through literature review we selected the materials (iron ore tailing and glass waste) which was used in this work for sand and cement replacement. Our first experimental work is finding physical properties of Ingredients used in concrete likely cement's physical property (specific gravity, Initial and final setting time), Glass powder's specific gravity, Iron ore tailing's specific gravity after sieving with $2.36 \mathrm{~mm}$ sieve, Fine aggregate's specific gravity, coarse aggregate's physical properties (Specific gravity, water absorption, impact and crushing value). After that proportioning the mix as per IS 10262:2009 was done. Followed to that we started casting concrete cubes (for finding compressive strength and water absorption of concrete), Cylinders (for finding Split tensile strength and Modulas of elasticity of concrete) and Prism beam (for finding Flexural strength of concrete). After that the results for concrete with and without IOT and glass waste was analyzed and discussed by comparing previous research work. Materials use in support of experimental study were sand, cement, iron ore tailing glass powder, aggregates and water. The description of each of the materials is given in the following sections.

\subsection{Cement and glass powder}

OPC 53grade conforming IS12269:2013 [29] is used this experimental examination. Physical properties of cement are given in Table 1. Finely powdered glass powder of specific gravity 2.6 is used. Glass powder used for this study is shown in figure 1.

Table 1: Cement Physical property

\begin{tabular}{|c|c|c|c|}
\hline $\begin{array}{c}\text { Sl } \\
\text { no }\end{array}$ & Properties & Values obtained & $\begin{array}{c}\text { Requirement as per IS } \\
12269: 2013\end{array}$ \\
\hline 1 & Specific gravity & 3.15 & - \\
\hline 2 & Initial setting time & 60 minutes & Should be more than 30 minutes \\
\hline 3 & Final setting time & 450 minutes & Should be less than 600minutes \\
\hline
\end{tabular}

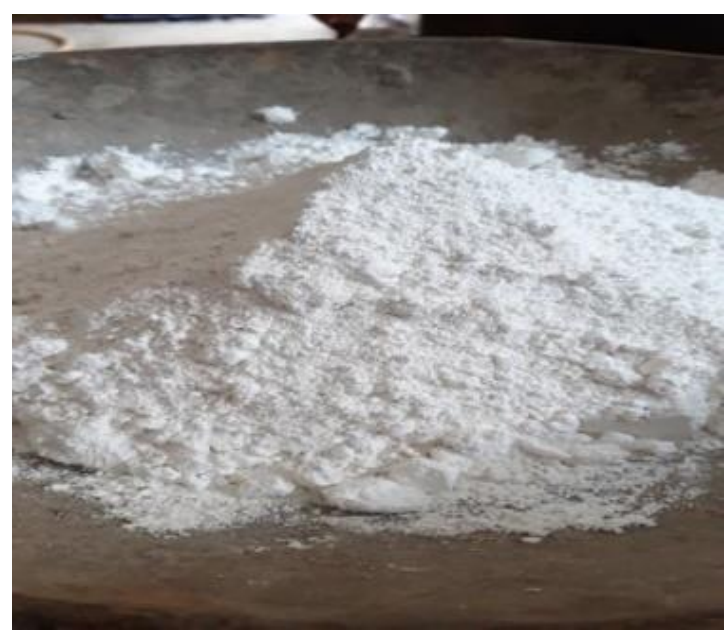

Figure 1: Glass powder 


\subsection{Iron Ore Tailings and fine aggregate}

Iron ore tailing passing through $2.36 \mathrm{~mm}$ IS sieve is used for this experimental programme. Specific gravity of IOT was discovered to be is 3.31. Iron ore tailing used for this study was shown in figure 2 . The sand used does not contain any organic matter and it is free from impurities. SG of river sand be determined as per IS 2386- Part I: 1963[30]. River sand conforming IS383: 1970 [31], passing through sieve $4.75 \mathrm{~mm}$ is worn for present investigation as fine aggregate. The specific gravity was found to be 2.70 . Sieve analysis results of fine aggregate given in Table 2.

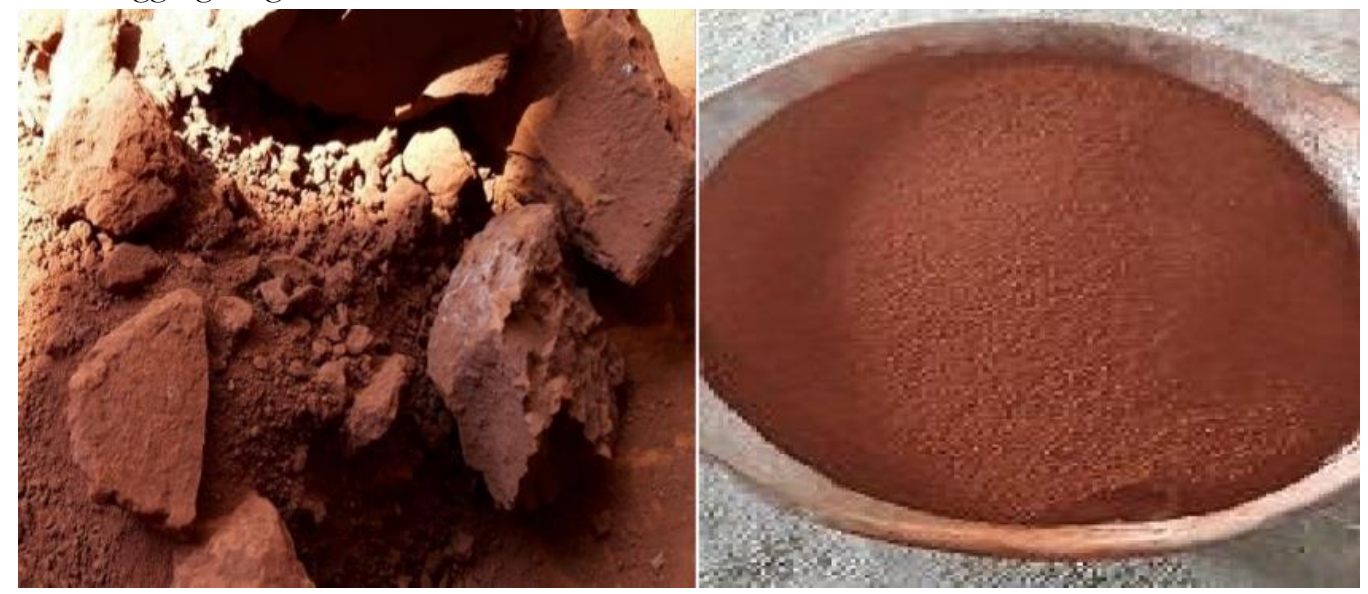

Figure 2: Raw iron ore tailings and crushed iron ore tailings

Table 2: Sieve analysis result of fine aggregate (Sample-1000 gms)

\begin{tabular}{|c|c|c|c|c|c|}
\hline Is sieve (mm) & $\begin{array}{c}\text { Weight } \\
\text { Retained } \\
\text { (gram) }\end{array}$ & $\begin{array}{c}\text { \% Weight } \\
\text { Retained }\end{array}$ & $\begin{array}{c}\text { Cumulative } \\
\text { \% Weight } \\
\text { Retained }\end{array}$ & $\begin{array}{c}\text { \% Weight } \\
\text { passing }\end{array}$ & $\begin{array}{c}\text { IS 383:1970 } \\
\text { Requirement } \\
\text { for grading } \\
\text { Zone-2 }\end{array}$ \\
\hline 10 & - & - & - & 100 & 100 \\
\hline 4.75 & 0 & 0 & 0 & 100 & $90-100$ \\
\hline 2.36 & 26.3 & 2.63 & 2.63 & 97.37 & $75-100$ \\
\hline 1.18 & 178 & 17.8 & 20.43 & 79.57 & $55-90$ \\
\hline 0.60 & 250 & 25 & 45.43 & 54.57 & $35-59$ \\
\hline 0.30 & 382 & 38.2 & 83.63 & 16.37 & $8-30$ \\
\hline 0.15 & 147.2 & 14.72 & 98.35 & 1.65 & $0-10$ \\
\hline
\end{tabular}

\subsection{Coarse aggregate}

Stone of size $10 \mathrm{~mm} \& 20 \mathrm{~mm}$ size which be locally available is used as coarse aggregate. In current analysis, the aggregates were $20 \mathrm{~mm}$ and $10 \mathrm{~mm}$ in size, respectively proportion $60 \%$ and $40 \%$ by weight are used. Confirms to IS 383: 1970 [31] "specifications for coarse and fine aggregates". Physical properties of CA given in Table 3 and sieve analysis report of CA given in Table 4.

Table 3: coarse aggregate Physical property

\begin{tabular}{|c|c|c|c|}
\hline $\begin{array}{c}\text { Sl } \\
\text { no }\end{array}$ & Tests & Results & $\begin{array}{c}\text { IS Recommendation } \\
\text { (IS 383:1970) }\end{array}$ \\
\hline 1 & Specific gravity & 2.8 & - \\
\hline 2 & Water absorption & 1.7 & $<2 \%$ \\
\hline 3 & Impact value & 10.9 & $<30 \%$ \\
\hline 4 & Crushing value & 13.8 & $\begin{array}{c}30 \% \text { maximum for Road, } \\
\text { Runway and Pavement }\end{array}$ \\
\hline
\end{tabular}


Study on Properties of Concrete with Iron Ore Tailing and Glass Waste

Table 4: coarse aggregate sieve result (Sample-5kg)

\begin{tabular}{|c|c|c|c|c|c|}
\hline $\begin{array}{c}\text { IS } \\
\text { sieve } \\
\text { size } \\
(\mathrm{mm})\end{array}$ & $\begin{array}{c}\text { Weight } \\
\text { Retained (kg) }\end{array}$ & $\begin{array}{c}\% \\
\text { weight } \\
\text { Retained }\end{array}$ & $\begin{array}{c}\text { Cumulative \% } \\
\text { Weight retained }\end{array}$ & $\begin{array}{c}\% \\
\text { passing }\end{array}$ & $\begin{array}{c}\text { IS 383:1970 } \\
\text { Requirement (\% passing } \\
\text { graded aggregate of nominal } \\
\text { size 20mm) }\end{array}$ \\
\hline 40 & 0 & 0 & 0 & 100 & 100 \\
\hline 20 & 0.21 & 4.2 & 4.2 & 95.8 & $95-100$ \\
\hline 10 & 3.48 & 69.6 & 73.8 & 26.2 & $25-55$ \\
\hline 4.75 & 1.27 & 25.4 & 99.2 & 0.8 & $0-10$ \\
\hline
\end{tabular}

\subsection{Water and Chemical Admixtures}

Water is very important in concrete mix; it directly affect strength property plus the workability of mix. Specific quantity of water is required for hydration reaction to gain strength. Adequate water should add in concrete mix to attain desired strength and workability. Super plasticizing admixture is a type of high range water reducing chemical admixture. In this study conplast SP430 is used in concrete mixes as chemical admixture to make keep concrete in workable condition and to avoid particle segregation (gravel, coarse and fine sand).

\subsection{Mix design}

We followed IS10262:2009 code for proportioning various ingredients in concrete Mix. The weights of ingredients for concrete mix with and without IOT and glass waste are given in table 5 below.

Table 5: weight of ingredients

\begin{tabular}{|c|c|c|c|c|c|}
\hline Mix Number & 1 & 2 & 3 & 4 & 5 \\
\hline Material & $\begin{array}{c}\text { GP-0\% IOT- } \\
0 \%\end{array}$ & $\begin{array}{c}\text { GP-0\% IOT- } \\
30 \%\end{array}$ & $\begin{array}{c}\text { GP-10\% IOT- } \\
30 \%\end{array}$ & $\begin{array}{c}\text { GP-20\% IOT- } \\
30 \%\end{array}$ & $\begin{array}{c}\text { GP-30\% IOT- } \\
30 \%\end{array}$ \\
\hline Cement $\left(\mathrm{kg} / \mathrm{m}^{3}\right)$ & 394 & 394 & 354.6 & 315.2 & 275.8 \\
\hline $\begin{array}{c}\text { Glass powder } \\
\left(\mathrm{kg} / \mathrm{m}^{3}\right)\end{array}$ & - & - & 39.4 & 78.8 & 118.2 \\
\hline $\begin{array}{c}\text { Fine aggregate } \\
\left(\mathrm{kg} / \mathrm{m}^{3}\right)\end{array}$ & 807.408 & 862.12 & 858.49 & 854.86 & 852.44 \\
\hline $\begin{array}{c}\text { Coarse } \\
\text { aggregate }(\mathrm{kg} \\
\left./ \mathrm{m}^{3}\right)\end{array}$ & 1156.28 & 1156.28 & 1151.4 & 1146.53 & 1143.28 \\
\hline Water $\left(\right.$ lit $\left./ \mathrm{m}^{3}\right)$ & 157.6 & 157.6 & 157.6 & 157.6 & 157.6 \\
\hline $\begin{array}{c}\text { Super } \\
\text { plasticizer }(\text { lit } \\
\left./ \mathrm{m}^{3}\right)\end{array}$ & 7.88 & 7.88 & 7.88 & 7.88 & 7.88 \\
\hline
\end{tabular}

\section{Results}

\subsection{Fresh Properties of concrete}

Concrete Workability is the trait of fresh concrete mix, which represents the mixing, transporting, moulding, compacting ability of concrete. Workability is directly depending on water- cement ratio; workability rises with the rise in water to cement relation. Workability of fresh concrete is helpful to knowing the bleeding and segregation. $100 \mathrm{~mm}$ is the top diameter, $200 \mathrm{~mm}$ is the bottom diameter and $300 \mathrm{~mm}$ is the height of slump cone. Temping rod was used to compact and remove the air voids. Slump value of concrete measured in 'mm' as per IS 1199: 1959 [32]. Slump value for various mixes given in Table 6. 
Sushmitha \& Dhanabal, J. Mod. Mater; Vol. 8, Issue 1, pp: 30-39, 2021

Table 6: Slump values of mixes

\begin{tabular}{|c|c|c|}
\hline Concrete mix & Mix Number & Slump (mm) \\
\hline Control mix & 1 & $45 \mathrm{~mm}$ \\
\hline $0 \%$ GP and 30\% IOT & 2 & $43 \mathrm{~mm}$ \\
\hline $10 \%$ GP and 30\% IOT & 3 & $41 \mathrm{~mm}$ \\
\hline $20 \%$ GP and 30\% IOT & 4 & $39 \mathrm{~mm}$ \\
\hline $30 \%$ GP and 30\% IOT & 5 & $38 \mathrm{~mm}$ \\
\hline
\end{tabular}

\subsection{Hardened Properties of concrete}

Density of cubes for all concrete mix with varying glass powder and constant iron ore tailings as replacement was determined. Density of concrete cubes was determined on concrete cube of $100 \mathrm{~mm} x$ $100 \mathrm{~mm} \times 100 \mathrm{~mm}$ size at 7 and 28 days curing. The density of different mixes at 7 days shown in the below table 7 .

Table 7: Density of mixes

\begin{tabular}{|l|c|c|}
\hline Concrete mix & Mix Number & Density $(\mathrm{kg} / \mathrm{m} 3)$ \\
\hline Control mix & 1 & 2456 \\
\hline $0 \%$ GP and 30\% IOT & 2 & 2510 \\
\hline $10 \%$ GP and 30\% IOT & 3 & 2521 \\
\hline $20 \%$ GP and 30\% IOT & 4 & 2604 \\
\hline $30 \%$ GP and 30\% IOT & 5 & 2548 \\
\hline
\end{tabular}

The compressive strength value is important criteria for study the properties of concrete. To found the compressive strength a cube of $100 * 100 * 100 \mathrm{~mm}$ casted and the testing of cubes were done in compression testing machine capacity $2000 \mathrm{kN}$, as per IS516: 1959 [32]. Maximum load at which the sample fails can be written down to calculate compressive strength. Compressive strength results for various mixes shown in figure 3.

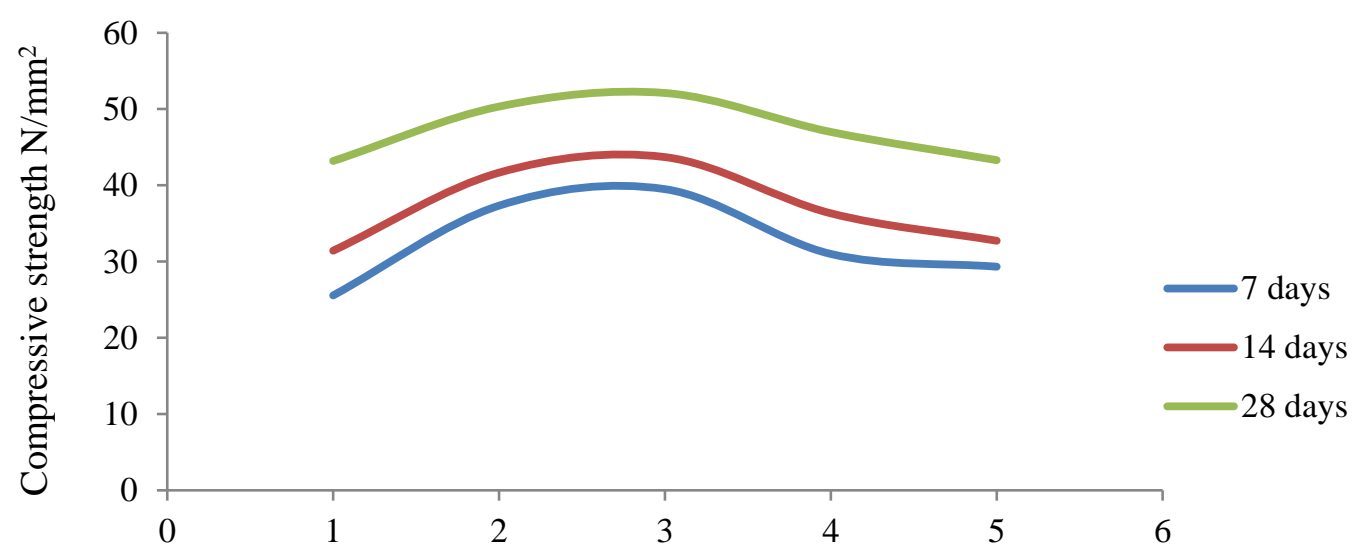

Conventional and waste replaced concrete mix

Figure 3: Compressive strength of concrete of all mixes 
Study on Properties of Concrete with Iron Ore Tailing and Glass Waste

Similar to compressive strength values, flexural strength values, splitting tensile strength values for $10 \%$ glass powder concrete mix were maximum. Hence for concrete mix with $10 \%$ glass powder and $30 \%$ IOT flexural strength is maximum. Split tensile strength results for various mixes shown in figure 4.

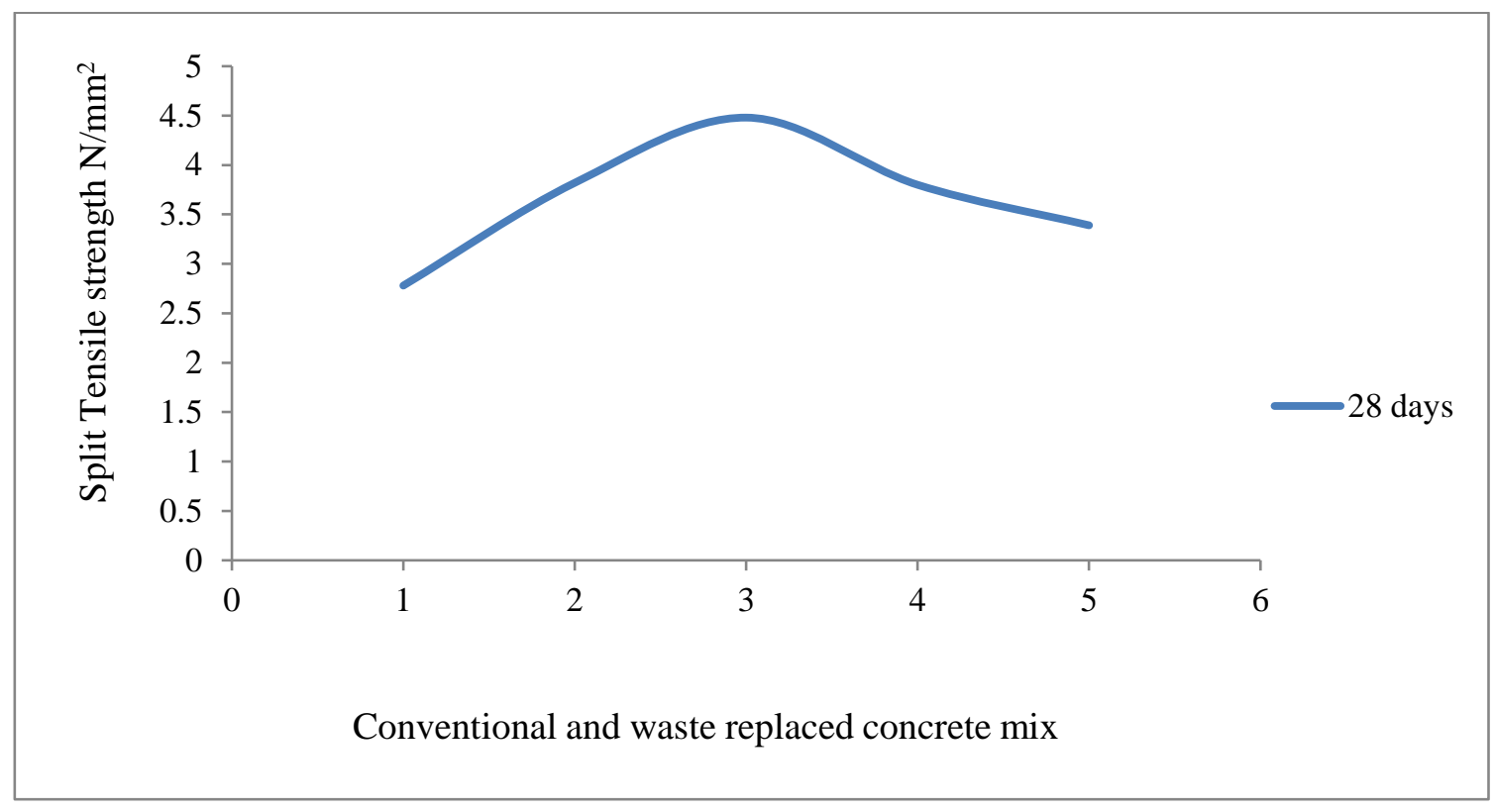

Figure 4: Splitting tensile strength of all mixes

Same as the compressive strength test results, flexural strength for 10\% glass powder concrete mix showed maximum strength. Hence for concrete blend with 10\% glass powder and 30\% IOT, flexural strength be maximum. Flexural strength results for various mixes shown in figure 5 .

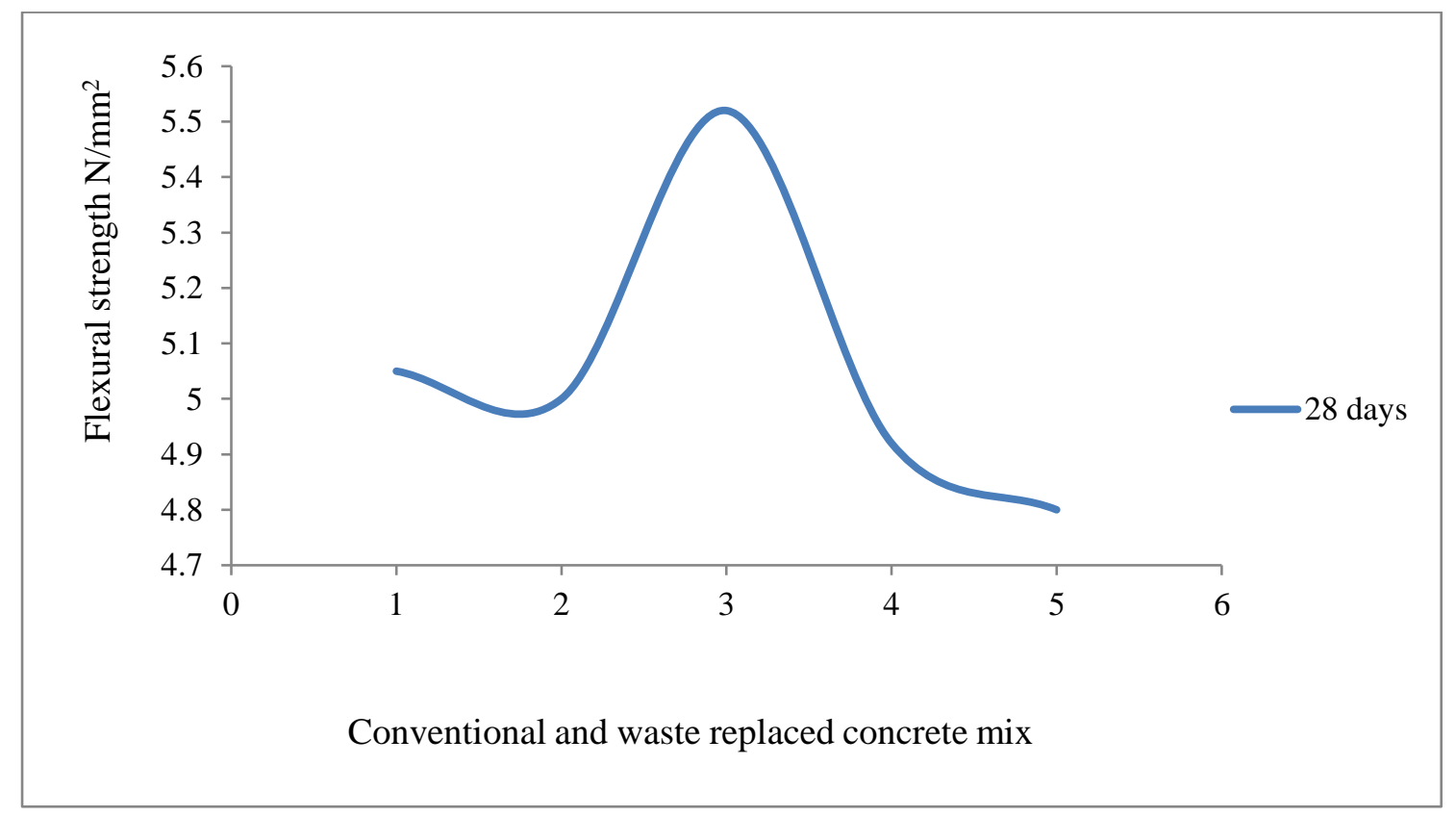

Figure 5: Flexural strength of concrete mixes for 28 days

Absorption of Water test conducted on $100 * 100 * 100$ size cubes. From the test result values, water absorption for mixes decreasing with increasing percentage of GP. Water absorption results for various mixes shown in figure 6 . 


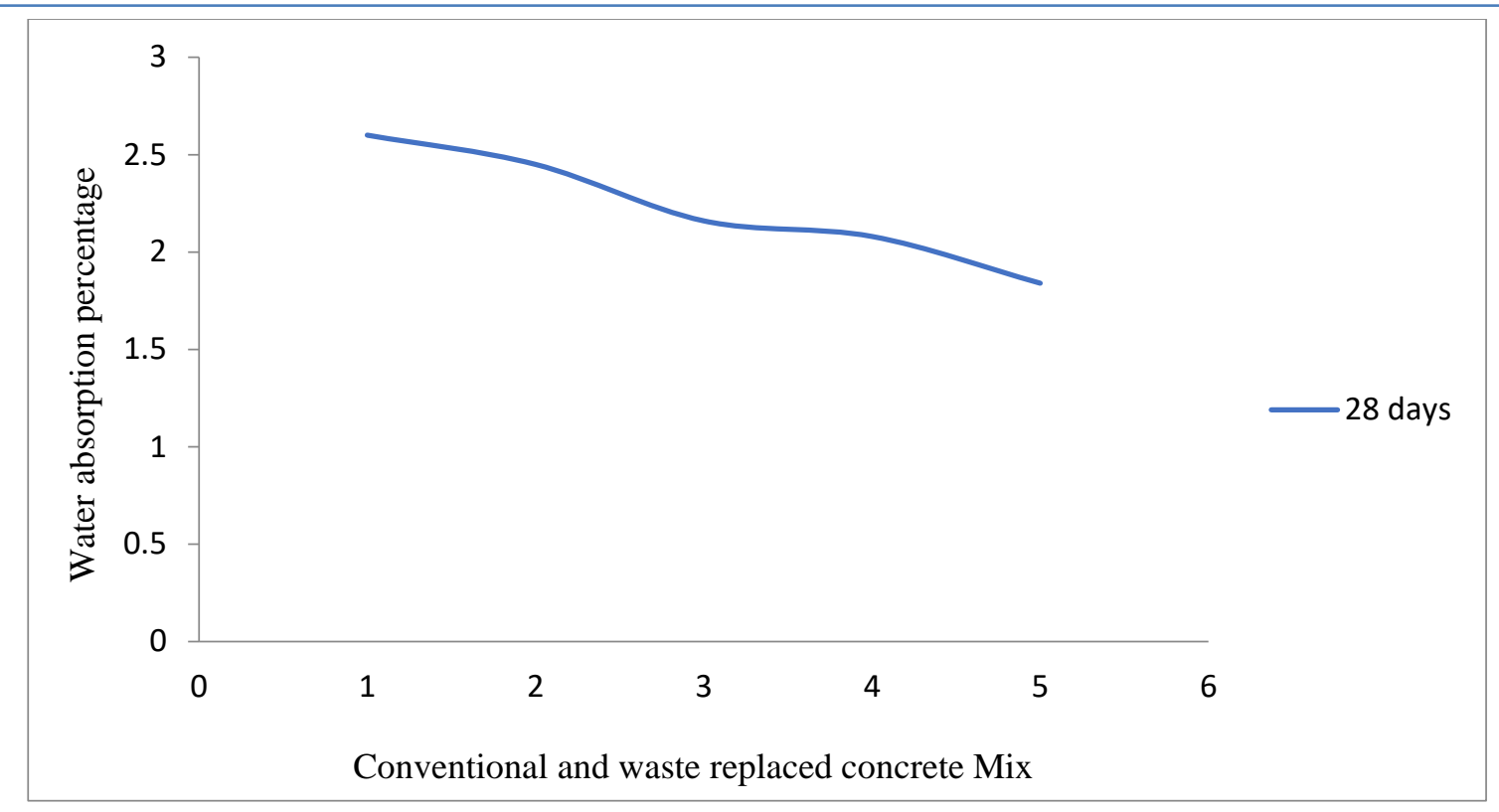

Figure 6: Water absorption of cubes for 28 days

Compressive strength predominantly affects stress to strain value of concrete. Maximum Young's Modulas of concrete achieved at 10\% substitution of cement with glass powder. Modulas of elasticity results for various mixes shown in figure 7 .

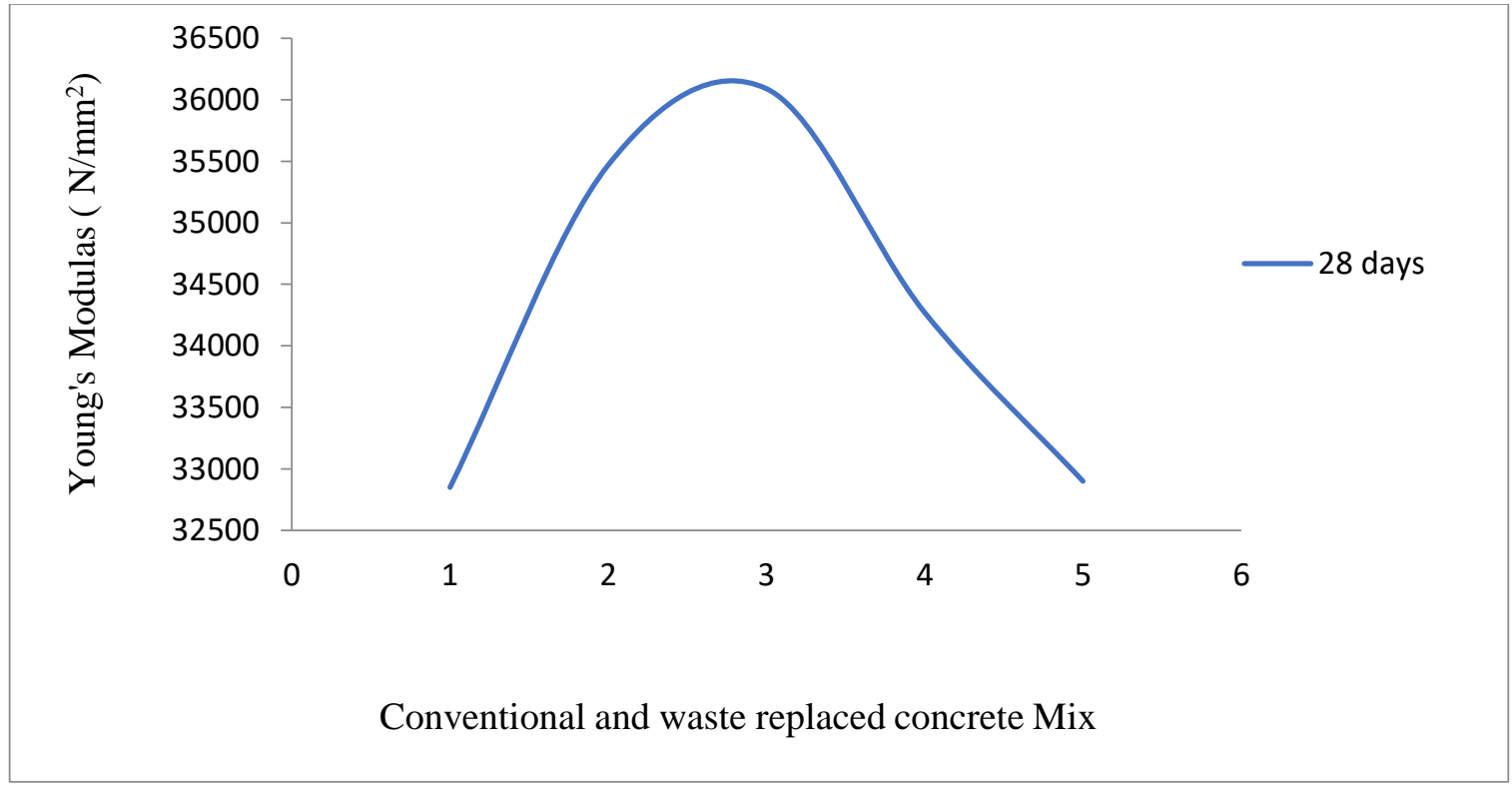

Figure 7: Modulas of elasticity results for various mixes

\section{Discussion}

Study was conducted to find the optimum percentage of replacement of glass waste as cement and Iron ore tailing as fine aggregate. It is observed that concrete with 10 percent glass waste and 30 percent IOT gives more compressive strength comparing all mix including conventional concrete mix. Result from experimental investigation was discussed as follows.

\subsection{Fresh property and density}

From slump cone test, we get to know that concrete with zero percent glass waste as cement and 30 percentage as FA gives more slump $(43 \mathrm{~mm})$ comparing all other mix. Also, the result shows that when increase in glass waste replacement percentage with 30 percentages IOT leads to reduction in Slump value. 
Study on Properties of Concrete with Iron Ore Tailing and Glass Waste

So, through this research we found that glass waste (alone) as cement will increase workability but when we combine both IOT and glass waste in concrete then it will not enhance the workability of concrete mix. So combined IOT and Glass waste was not suitable where there is a need of high workability.

concrete with $20 \%$ GP as cement $+30 \%$ IOT as fine aggregate was given $6 \%$ more density $(2604$ $\mathrm{kg} / \mathrm{m} 3)$ by comparing conventional concrete density $(2456 \mathrm{~kg} / \mathrm{m} 3)$. From results, we found that, when increase in GP percentage with 30 percent IOT will leads to increase in density of concrete. So we can combine both iron ore tailing and glass waste and use in high density kind of special concrete where density playing important role.

\subsection{Hardened properties and water absorption of concrete}

Compressive strength of conventional concrete at age 7, 14 and 28 days was $25.56 \mathrm{~N} / \mathrm{mm} 2,31.43$ $\mathrm{N} / \mathrm{mm} 2$ and $43.19 \mathrm{~N} / \mathrm{mm} 2$ respectively. When replacing GP with $30 \%$ IOT results in high strength in all mix, but concrete with $10 \%$ GP and $30 \%$ IOT gives $54 \%$ (39.5 N/mm2), 39\% (N/mm243.70) and $20 \%$ $(52.11 \mathrm{~N} / \mathrm{mm} 2)$ more strength at age of 7,14 and 28 days. From results we observed that, 10 percentage of GP with $30 \% \mathrm{~b}$ IOT is the nominal mix percentage to produce concrete with high compressive strength. Concrete with $20 \%$ and $30 \%$ Glass powder gives $10 \%(47 \mathrm{~N} / \mathrm{mm} 2)$ and $21 \%(43.33 \mathrm{~N} / \mathrm{mm} 2)$ less compressive strength compared to concrete with $10 \%$ GP and $30 \%$ IOT at 28 days. We found the optimum mix of combined IOT and Glass waste replacement $(10 \% \mathrm{GP}+30 \%$ IOT) to attain maximum compressive strength. Also, if increase in GP takes place with constant 30\% IOT then there will be a decrease in compressive strength.

At 28 days, the split tensile strength of conventional concrete was found $2.78 \mathrm{~N} / \mathrm{mm} 2$, it was $61 \%$ less compared to tensile strength of concrete with $10 \% \mathrm{GP}+30 \%$ IOT $(4.48 \mathrm{~N} / \mathrm{mm} 2)$. Results show that there was an increase in tensile strength when GP replaced as cement with $30 \%$ IOT. But about $10 \%$ GP, there was a reduction in tensile strength. So we can fix $10 \%$ GP waste as nominal replacement percentage to get high tensile strength. In Split tensile strength test we found combined IOT and GP (10\% GP + 30 $\%$ IOT) replacement can enhance the tensile potency of concrete element but not more than 5 percentages.

Flexural strength of concrete with $10 \% \mathrm{GP}+30 \%$ IOT was $5.52 \mathrm{~N} / \mathrm{mm} 2$ at 28 days; it was 9 percentages more comparing to Conventional concrete flexural strength $5.05 \mathrm{~N} / \mathrm{mm} 2$. From results its observed that 10 percentage GP and $30 \%$ IOT produces more flexure concrete comparing all other mixes. We noticed that combined IOT and Glass waste (Optimum dosage $=10 \%$ GP $+30 \%$ IOT) will help to increase the flexural strength of concrete but not more. So combined IOT and glass waste concrete not preferable where high flexural strength needed.

Concrete with $10 \%$ GP with $30 \%$ IOT gives maximum Modulas of elasticity $36.09 * 103 \mathrm{MPa}$ at 28 days .it was 9 percentages more compared to conventional concrete $32.85 * 103 \mathrm{MPa}$. From investigation we concluded that use of Glass powder with 30 percentages IOT results in increment of young's Modulas, but $10 \%$ GP $+30 \%$ IOT produces maximum. So we found through optimum dosage of combined concrete with IOT and glass waste (10\% GP $+30 \%$ IOT) can help to enhance the elasticity of the specimen but not at high level.

Concrete with $30 \%$ Glass powder and 30 Percent IOT absorbing less water $1.84 \%$ at 28 days, it was 41 percentage less compared to water absorption of conventional concrete $2.6 \%$. So when percentage of GP replacement increases means, it will reduce the water absorption level of concrete. Combined glass waste and IOT concrete element (30\% GP + 30\% IOT) can perform well in terms of water absorption criteria.

\section{Conclusions}

Through this current study we archived following consequences. Firstly, we found that the combined IOT and Glass waste $(10 \% \mathrm{GP}+30 \%$ IOT) at optimum percentage of replacement as fine aggregate and cement can be performing good in all strength aspect likely compressive strength, Split tensile Strength, Flexural Strength and Modulas of elasticity of concrete. But when comes to fresh properties of concrete 
aspect, there will be no significant enhancement in workability and flow ability in concrete because of combined effect of IOT and glass waste. In durability aspect we found that there was a reduction in water absorption when increase in glass waste powder with 30 percent IOT as fine aggregate. So, from our research findings we are concluding that Concrete with IOT and glass waste combination was suitable to use in construction industry to reduce the demand of cement and river sand.

\section{Competing Interests}

The authors declared that they have no conflict of Interest.

\section{How to Cite this Article:}

K. Sushmitha and P. Dhanabal, "Study on Properties of Concrete with Iron Ore Tailing and Glass Waste", J. Mod. Mater., vol. 8, no. 1, pp. 30-39, Dec. 2021.

\section{References}

[1] Ana Cristina Vieira Zuccheratte, Carolina Braccini Freire, Fernando Soares Lameiras, "Synthetic gravel for concrete obtained from sandy iron ore tailing and recycled polyethyltherephtalate", Construction and Building Materials, Volume 151,2017, Pages 859-865, https://doi.org/10.1016/j.conbuildmat.2017.06.133.

[2] Tony Matheus Carvalho Eugênio, Jefferson Francisco Fagundes, Queilla Santos Viana, Alan Pereira Vilela, Rafael Farinassi Mendes, "Study on the feasibility of using iron ore tailing (iot) on technological properties of concrete roof tiles", Construction and Building Materials, Volume 279,2021, https://doi.org/10.1016/j.conbuildmat.2021.122484

[3] P Dhanabal, K S Sushmitha, P. Narendra Reddy, "Study on properties of concrete with Electronic waste", Revista Ingenieria de construccion, Volume 36, No 1 (2021), Pages 48-58, http://dx.doi.org/10.4067/S0718-50732021000100048

[4] B. Karthikeyan, R. Kathyayini, V. Aravindh Kumar, V. Uthra, Selvaraj Senthil Kumaran, "Effect of dumped iron ore tailing waste as fine aggregate with steel and basalt fibre in improving the performance of concrete", Materials Today: Proceedings, 2021, https://doi.org/10.1016/j.matpr.2021.01.906

[5] Fanghui Han, Shaomin Song, Juanhong Liu, Shun Huang, "Properties of steam-cured precast concrete containing iron tailing powder", Powder Technology, Volume 345,2019, Pages 292-299, https://doi.org/10.1016/j.powtec.2019.01.007

[6] Ping Duan, Chunjie Yan, Wei Zhou, Daming Ren, "Development of fly ash and iron ore tailing based porous geopolymer for removal of $\mathrm{Cu}$ (II) from waste water", Ceramics International, Volume 42, Issue 12,2016, Pages 13507-13518, https://doi.org/10.1016/j.ceramint.2016.05.143

[7] Ali Umara Shettima, Mohd Warid Hussin, Yusof Ahmad, Jahangir Mirza, "Evaluation of iron ore tailings as replacement for fine aggregate in concrete", Construction and Building Materials, Volume 120, 2016, Pages 72-79, https://doi.org/10.1016/j.conbuildmat.2016.05.095

[8] Keoma do Carmo e Silva Defáveri, LetíciaFigueiredo dos Santos, José Maria Franco de Carvalho, Ricardo André Fiorotti Peixoto, Guilherme Jorge Brigolini, "Iron ore tailing-based geopolymer containing glass wool residue: A study of mechanical and microstructural properties" Construction and Building Materials, Volume 220,2019, Pages 375-385, https://doi.org/10.1016/j.conbuildmat.2019.05.181

[9] Ping Duan, Chunjie Yan, Wei Zhou, Daming Ren, "Fresh properties, compressive strength and microstructure of fly ash geopolymer paste blended with iron ore tailing under thermal cycle", Construction and Building Materials, Volume 118,2016, Pages 76-88, https://doi.org/10.1016/j.conbuildmat.2016.05.059

[10] Fanghui Han, Ao Luo, Juanhong Liu, Zengqi Zhang, "Properties of high-volume iron tailing powder concrete under different curing conditions",Construction and Building Materials, Volume 241,2020,118108, https://doi.org/10.1016/j.conbuildmat.2020.118108 .

[11] 1Chang-long Wang, Wen Ni, Si-qi Zhang, Shuang Wang, Guo-sheng Gai, Wei-kang Wang, "Preparation and properties of autoclaved aerated concrete using coal gangue and iron ore tailings", Construction and Building Materials, Volume 104,2016, Pages 109-115, https://doi.org/10.1016/j.conbuildmat.2015.12.041.

[12] Blessen Skariah Thomas, Alok Damare, R.C. Gupta, "Strength and durability characteristics of copper tailing concrete", Construction and Building Materials,Volume 48,2013,Pages 894-900, https://doi.org/10.1016/j.conbuildmat.2013.07.075 .

[13] XingdongLv, Yuqiang Lin, Xia Chen, Yan Shi, Renqiang Liang, Rongkai Wang, Ziling Peng, "Environmental impact, durability performance, and interfacial transition zone of iron ore tailings utilized as dam concrete aggregates", Journal of Cleaner Production, Volume 292,2021,126068, https://doi.org/10.1016/j.jclepro.2021.126068

[14] Weifeng Zhang, Xiaowei Gu, JingpingQiu, Jianping Liu, Yunqi Zhao, Xiaohui Li, "Effects of iron ore tailings on the compressive strength and permeability of ultra-high performance concrete", Construction and Building Materials, Volume 260,2020,119917, https://doi.org/10.1016/j.conbuildmat.2020.119917

[15] Bao-guo Ma, Li-xiong Cai, Xiang-guo Li, Shou-wei Jian, "Utilization of iron tailings as substitute in autoclaved aerated concrete: physico-mechanical and microstructure of hydration products”, Journal of Cleaner Production, Volume 127,2016, Pages 162-171, https://doi.org/10.1016/j.jclepro.2016.03.172

[16] Jiangshan Zhao, Kun Ni, YoupoSu, Yunxing Shi, "An evaluation of iron ore tailings characteristics and iron ore tailings concrete properties", Construction and Building Materials, Volume 286, 2021. https://doi.org/10.1016/j.conbuildmat.2021.122968

[17] Vitor O. Almeida, Ivo A.H. Schneider, "Production of a ferric chloride coagulant by leaching an iron ore tailing", Minerals Engineering, Volume 156,2020,106511, https://doi.org/10.1016/j.mineng.2020.106511. 
Study on Properties of Concrete with Iron Ore Tailing and Glass Waste

[18] Lixiong Cai, Baoguo Ma, Xiangguo Li, Yang Lv, Zhuolin Liu, Shouwei Jian, "Mechanical and hydration characteristics of autoclaved aerated concrete (AAC) containing iron-tailings: Effect of content and fineness", Construction and Building Materials, Volume 128, 2016, Pages 361-372, https://doi.org/10.1016/j.conbuildmat.2016.10.031.

[19] N.A. Soliman, A. Tagnit-Hamou, "Development of ultra-high-performance concrete using glass powder - Towards ecofriendly concrete", Construction and Building Materials, Volume 125, 2016, Pages 600-612, https://doi.org/10.1016/j.conbuildmat.2016.08.073

[20] Ahmed Omran, ArezkiTagnit-Hamou, "Performance of glass-powder concrete in field applications", Construction and Building Materials, Volume 109,2016, Pages 84-95, https://doi.org/10.1016/j.conbuildmat.2016.02.006

[21] Hyeongi Lee, Asad Hanif, Muhammad Usman, Jongsung Sim, Hongseob Oh, "Performance evaluation of concrete incorporating glass powder and glass sludge wastes as supplementary cementing material”, Journal of Cleaner Production, Volume 170,2018, Pages 683-693, https://doi.org/10.1016/j.jclepro.2017.09.133.

[22] Ali A. Aliabdo, Abd Elmoaty M. Abd Elmoaty, Ahmed Y. Aboshama, "Utilization of waste glass powder in the production of cement and concrete", Construction and Building Materials, Volume 124, 2016, Pages 866-877, https://doi.org/10.1016/j.conbuildmat.2016.08.016

[23] Hongjian Du, Kiang Hwee Tan, "Properties of high volume glass powder concrete", Cement and Concrete Composites, Volume 75,2017, Pages 22-29, https://doi.org/10.1016/j.cemconcomp.2016.10.010.

[24] Zhi-hai He, Pei-min Zhan, Shi-gui Du, Bao-ju Liu, Wei-bin Yuan, "Creep behavior of concrete containing glass powder", Composites Part B: Engineering, Volume 166,2019, Pages 13-20, https://doi.org/10.1016/j.compositesb.2018.11.133

[25] Widodo Kushartomo, Ika Bali, Budi Sulaiman, "Mechanical Behavior of Reactive Powder Concrete with Glass Powder Substitute", Procedia Engineering, Volume 125,2015, Pages 617-622, https://doi.org/10.1016/j.proeng.2015.11.082.

[26] Nathan Schwarz, Hieu Cam, Narayanan Neithalath, "Influence of a fine glass powder on the durability characteristics of concrete and its comparison to fly ash", Cement and Concrete Composites, Volume 30, Issue 6,2008, Pages 486-496, https://doi.org/10.1016/j.cemconcomp.2008.02.001

[27] G.M. Sadiqul Islam, M.H. Rahman, NayemKazi, "Waste glass powder as partial replacement of cement for sustainable concrete practice", International Journal of Sustainable Built Environment, Volume 6, Issue 1,2017, Pages 37-44, https://doi.org/10.1016/j.ijsbe.2016.10.005

[28] Ahmad Shayan, Aimin Xu, "Performance of glass powder as a pozzolanic material in concrete: A field trial on concrete slabs", Cement and Concrete Research, Volume 36, Issue 3,2006, Pages 457-468, https://doi.org/10.1016/j.cemconres.2005.12.012

[29] "Specifications for 53 grade ordinary Portland cement", Bureau of Indian Standards (BIS), New Delhi, India, IS 12269, 2013.

[30] "Methods of tests for aggregates for concrete", Bureau of Indian Standards (BIS), New Delhi, India, IS 2386, 1963.

[31] "Specifications for coarse and fine aggregates", Bureau of Indian Standards (BIS), New Delhi, India, IS 383, 1970.

[32] "Methods of sampling and analysis of concrete", Bureau of Indian Standards (BIS), New Delhi, India, IS 1199, 1959.

[33] "Methods of test for strength of concrete", Bureau of Indian Standards (BIS), New Delhi, India, IS 516, 1959.

Publish your research article in AIJR journals-

- Online Submission and Tracking

- $\quad$ Peer-Reviewed

- Rapid decision

- Immediate Publication after acceptance

- Articles freely available online

- Retain full copyright of your article.

Submit your article at journals.aijr.org
Publish your books with AIJR publisher-

- Publish with ISBN and DOI.

- Publish Thesis/Dissertation as Monograph.

- Publish Book Monograph.

- Publish Edited Volume/ Book.

- Publish Conference Proceedings

- Retain full copyright of your books.

Submit your manuscript at books.aijr.org 